\title{
British Society of Gastroenterologists
}

\section{Annual Meeting at London}

List of Communications

Friday, November 7th, 1952

Witts, L. J.: Haemopoiesis in Relation to Disorders of the Alimentary Tract 322

Cuthbertson, W. F. J.: Haematological and Nutritional Effects of Oral Anti

biotics 327

Badenoch, J., and W. C. D. Richards: The Gastric Lesion in Anaemia, with

Particular Reference to Biopsy

Blake, J.: Haematological and Nutritional Effects of Operation on the Stomach 337

Ungley, C. C. (in collaboration with E. V. Cox, B. Schofield and R. B. Thomp

son): Megaloblastic Anaemia Following Operations on the Intestine

338

Davidson, L. S. P.: Megaloblastic Anaemia and Subacute Combined Degenera

tion from Tuberculous Disease of the Small Intestine $\quad 342$

Rechnitzer, P.: Three Cases of Small Intestinal Neoplasm 343

Richardson, J. E.: Two Unusual Small Intestinal Neoplasms, both with

Anaemia. Followed by - General Discussions $\quad 345$

Saturday, November 8th, 1952

Ihre, Bengt J. E.: Routine Sigmoidoscopy for the Early Detection of Rectal

Carcinoma 347

Chandler, G. JV·, and G. Watkinson: The Diagnostic Value of Gastric Aspiration

in Haematemesis 355

Dickinson, P. H. (for Key J. A.): Circulation of Blood in the Rat's Stomach.. 356

Jones, F. A.: Carcinoma of the Gallbladder - Statistical Study 357

Ardran, G. M., F. H. Kemp and S. C. Truelove: A Radiological Study of the

Movements of the Tongue, Pharynx and Oesophagus in Acrosclerosis .... 361

Ardran, G. M., J. Badenoch, F. H. Kemp and W. C. D. Richards: Deformity of the Lower End of the Oesophagus and the Adjacent Part of the Stomach

in Pernicious Anaemia 376

Wagstaff, J. K.: Demonstration - Post-Mortem Arteriography of the Normal

Stomach 378

Gaßtroenterologia, Vol. 79, No. 6 (1953) 